\title{
Factors Affecting Willingness to Pay for Outpatient Services at RSU Tangerang Selatan
}

\author{
Farah Elena Astrilia*, Yanti Harjono Hadiwiardjo, Gatot Soeryo \\ Undergraduate Medical Study Program, Department of Public Health Sciences, Faculty of \\ Medicine UPN “Veteran” Jakarta, Indonesia. \\ *corresponding author, e-mail: faarelena@yahoo.com
}

Received: 15/04/2020; published: 30/12/2020

\begin{abstract}
Background: The government established a national health insurance program (NHI) to increase access to health services but the program is still not optimal, it affects the number of hospital visits and income. Therefore it required an analysis of patient's willingness to pay out of pocket for outpatient services. The purpose of this study was to determine factors affecting patient's willingness to pay. Method: This research is a cross sectional study involving 124 internal medicine outpatients at General Hospital (RSU) South Tangerang City in November 2019. Data were obtained from a questionnaire. Patient's income, information, treatment experience, health insurance, distance to hospital, health service, ability to pay, and willingness to pay was investigated using chi square and logistic regression analysis. Results: The results outcomes showed that the level of willingness to pay of respondents is quite high and is influenced by patient's income $(p=0.001)$, information $(p=0.045)$, treatment experience $(p=$ $0.010)$, and ability to pay (ATP) $(p=0.001)$. Factors that have the most significant associations were patient's ability to pay $(\mathrm{OR}=14,502)$. Conclusion: Patient's income, information, treatment experience, and ATP affect the willingness to pay of patients.
\end{abstract}

Keywords: ability to pay; distance to hospital; health insurance; health service; income; information; treatment experience; willingness to pay

Copyright $\odot 2013$ Universitas Ahmad Dahlan. All rights reserved.

\section{Introduction}

Healthy is a state of well-being, perfect condition; either physically, mentally, or socially; which is not limited to being free from illness or weakness. Healthy can be achieved through various efforts, one of which is the implementation of health services [1]. All people are entitled to quality services in accordance with the balance between medical needs and economic capacity. This balance can be achieved by calculating health financing on the basis of the ability to pay and the willingness to pay, with the willingness to pay, it can be seen what the highest price someone is willing to pay as well as a measure of how much someone appreciates goods or services [2].

The World Health Organization (WHO) is making efforts in the form Universal Health Coverage $(\mathrm{UHC})$ to increase access to health services. Indonesia implements UHC through the National Health Insurance (NHI/Jaminan Kesehatan Nasional/JKN) program, which not only opening up access to health services but also increasing utilization at both the puskesmas (pusat kesehatan masyarakat/community health center) and the hospital [3]. In the $\mathrm{NHI}$ era, a tiered referral system in health services was established as an effort to control the quality and costs of the BPJS Kesehatan program. The Association of Indonesian Hospitals (Perhimpunan Rumah Sakit Seluruh Indonesia/PERSI) said that the system was still not optimal. The problems that arise include overcrowding in type D hospital which causing other hospitals to have a shortage of patients and some people have to go to a hospital that is far from their home. Other problems that arise are decreased hospital visits and income, complaints from people who cannot use their right to provide hospital services in their area, and uncertainty in service time due to piling up polyclinic queues [4]. 
RSU Kota Tangerang Selatan is a Type C hospital which is obliged to achieve work performance targets as a basis for assessing the success/failure of achieving goals and objectives. Performance achievements are seen from the financial aspect and the hospital service aspect. The 2018 Government Agencies Performance Report shows RSU Kota Tangerang has not met the performance target due to external and internal issues. Strategies are needed to achieve performance targets. One of these strategies is to increase income and increase the growth rate of outpatient visits [5].

Several conducted studies have not shown the effect of having insurance on the willingness to pay for outpatient care in the hospital. Therefore, the researcher is interested in conducting research on insurance ownership and its effect on the patient's willingness to pay out of their own pocket, and other influencing factors.

\section{Method}

The type of this research is a quantitative study with a cross sectional design approach i.e. research conducted at the same time both on the independent variable and the dependent variable [6]. The study was conducted in November 2019. The population studied were all patients who visited RSU Kota Tangeraang Selatan in November 2019. The sample selected was 124 patients who came to use outpatient services at the internal medicine polyclinic. Sampling was carried out at the internal medicine clinic with the highest percentage of visits per year $(10.55 \%)$ so that it could meet the required sample size. Obtaining this sample is a limitation of the study because it cannot generalize the study population. The inclusion criteria of this study are patients who have used outpatient services, adults to the late elderly according to the Indonesian Department of Health (Depkes RI) 2009 (26-65 years), were domiciled in South Tangerang, had a number of family members 1-4 people, the last level of education is in university, non-postoperative and supporting examinations patients, and patients were willing to participate in the study. The exclusion criteria included patients who refused to participate in the study, patients who had difficulties in communication, and patients who had special precautions or in emergency.

The dependent variable used in this study is the patients' willingness to pay out of their own pocket regarding outpatient services. While the independent variables used include the patients' monthly income, the distance from the patients' residence to the hospital, the experience of going to other health facilities, information obtained by patients regarding outpatient services, satisfaction with health services, ownership of insurance and the ability of patients to pay for services received by the patient. The instrument used in this study was a questionnaire. Data analysis was performed univariate to multivariate using SPSS 22 software.

\section{Result and Discussion}

\subsection{Result}

The results obtained indicate that of the 124 respondents, most of the respondents live $>4 \mathrm{~km}$ (58.9\%), have an income >Rp. 3.841.368,19,- (50.8\%) with government insurance ownership i.e. BPJS Kesehatan (89.5\%), have had treatment elsewhere $(62.1 \%)$ and have received information related to outpatient care before $(62.1 \%)$. In addition, (91.9\%) respondents received good health services and most patients could afford outpatient services (65.3\%). Details can be seen in Table 1.

Table 1. Characteristics of Research Respondents

\begin{tabular}{lcc}
\hline \multicolumn{1}{c}{ Variable } & $\mathbf{n}$ & $\%$ \\
\hline $\begin{array}{l}\text { Residence Distance } \\
\quad \leq 4 \mathrm{~km}\end{array}$ & 51 & 41.1 \\
$\quad>4 \mathrm{~km}$ & 73 & 58.9 \\
$\begin{array}{l}\text { Income } \\
\quad \text { <Rp. 3.841.368,19,- }\end{array}$ & 61 & 49.2 \\
$\quad$ >Rp. 3.841.368,19,- & 63 & 50.8 \\
Insurance Ownership & & \\
$\quad$ Government Insurance/BPJS Kesehatan & 111 & 89.5 \\
$\quad$ Private Insurance & 13 & 10.5
\end{tabular}




\begin{tabular}{lcc}
\multicolumn{1}{c}{ Variable } & $\mathbf{n}$ & $\%$ \\
\hline $\begin{array}{l}\text { Experienced Treatment Elsewhere } \\
\text { Yes }\end{array}$ & 77 & 62.1 \\
$\quad$ No & 47 & 37.9 \\
$\begin{array}{l}\text { Information } \\
\text { Yes }\end{array}$ & 67 & 54 \\
$\quad$ No & 57 & 46 \\
Health services & 114 & 91.9 \\
$\quad$ Good & 10 & 8.1 \\
$\quad$ Not Good & & 65.3 \\
Ability to pay & 81 & 34.7 \\
$\quad$ Capable & 43 & 78.2 \\
$\quad$ Not Capable & & 21.8 \\
Willingness to pay & 97 & \\
$\quad$ Will & 27 & \\
$\quad$ Unwill & & \\
\hline
\end{tabular}

The results of the multivariate analysis show that the variables that influence the willingness to pay from the patients' own pocket for outpatient service included income (Adj.PR $=2.64 ; 95 \% \mathrm{Cl}=0.69-10.12 ; \mathrm{p}$-value $<0.05)$, experienced treatment elsewhere (Adj.PR $=0.46 ; 95 \% \mathrm{Cl}=0.15-1.38 ; \mathrm{p}$-value $<0.05$ ) and ability to pay (Adj.PR $=14.50$; $95 \% \mathrm{Cl}=4.12-51.00 ; \mathrm{p}$-value $<0.05)$. More details can be seen in Table 2.

Tabel 2. Multivariate Analysis Results

\begin{tabular}{|c|c|c|c|c|c|}
\hline Variabel & Crude PR & $95 \% \mathrm{Cl}$ & $\begin{array}{c}\text { Adjusted } \\
\text { PR }\end{array}$ & $95 \% \mathrm{Cl}$ & p-value \\
\hline $\begin{array}{l}\text { Residence Distance } \\
\leq 4 \mathrm{~km} \\
>4 \mathrm{~km}\end{array}$ & 0,57 & $0.24-1.35$ & & & 0.200 \\
\hline $\begin{array}{l}\text { Income } \\
\quad \text { <Rp. 3.841.368,19,-- } \\
\text { >Rp. 3.841.368,19,-- } \\
\text { Insurance Ownership } \\
\text { Government Insurance/BPJS } \\
\text { Kesehatan } \\
\text { Private Insurance/Personal }\end{array}$ & 8,92 & $2.86-27.8$ & 2.64 & $0.69-10.12$ & 0.001 \\
\hline $\begin{array}{l}\text { Experienced Treatment Elsewhere } \\
\text { Yes } \\
\text { No }\end{array}$ & 0,32 & $0.13-0.77$ & 0.46 & $0.15-1.38$ & 0.010 \\
\hline $\begin{array}{c}\text { Information } \\
\text { Yes } \\
\text { No }\end{array}$ & 0,41 & $0.17-0.99$ & & & 0.045 \\
\hline $\begin{array}{l}\text { Health Services } \\
\text { Good } \\
\text { Not Good }\end{array}$ & 0,89 & $0.17-4.46$ & & & 1.000 \\
\hline $\begin{array}{l}\text { Ability to Pay } \\
\text { Capable } \\
\text { Not Capable } \\
\end{array}$ & 22,13 & $6.86-71.34$ & 14.50 & $4.12-51.00$ & 0.001 \\
\hline
\end{tabular}

\subsection{Discussion}

The results showed that income affects the patients' willingness to pay out of their pocket for outpatient services at RSU Kota Tangerang Selatan. This happens because increased income will also be followed by an increase in the number of goods and health services. In contrast, low-income people will fulfill their needs for goods first, then when their needs of essential goods are satisfied, they will then pay for health. Income along with non-food expenditure can determine a person's ability to pay (ATP), where it is assumed that a person will be able to spend money for essential health needs because they are able to spend money for secondary needs [7]. Patients who are willing to pay mean that they have sufficient income to pay for health services and can allocate their expenses for health costs. It is proven from the results of the study that 
the ability to pay (ATP) affects the willingness to pay of patients. The results of this study are consistent with previous research which concluded that with an increase in income and compensation for workers, the ability to pay for a health service will increase and will be followed by an increase in the willingness to pay out of pocket. [8]. Besides, a person's inability to pay for treatment is the main reason a person is not willing to pay for treatment [9].

In this study, treatment experience affects the willingness to pay, although the majority of respondents have experience in other places, the services and rates at the RSU Kota Tangerang Selatan are still considered good. This can be considered as a comparison with other health facilities which in turn can affect the willingness to pay. Treatment experience can affect a patient's willingness to pay due to a patient comparison. Hospitals must improve the quality of their health services so that the patients' willingness to pay can be increased. This willingness to pay assessment can also be used to determine service rates so that the public will be willing to pay and not choose another hospital [10]. Meanwhile, health services do not affect the patient's willingness to pay for outpatient services. This can be possible because the majority of outpatients in the internal medicine clinic are patients who have been treated for a long time or patients who have repeatedly been treated at RSU Kota Tangerang Selatan. So that health services are not the main consideration for patients to decide to pay.

The results also showed that there was no significant relationship between the distance of residence and the patients' willingness to pay out of their pocket. It is in accordance with previous research that there is no relationship between distance traveled and the use of services at the Puskesmas [12]. However, this is different from other researchers who state that there is a significant relationship between distance of residence and the level of visits to health services [10]. The distance of residence can be one of the driving factors i.e. the further away the place to live, the lower the level of visits and utilization of health facilities due to the more time and energy spentThe results of this study are different from previous studies because for respondents the distance of residence is not a decisive factor in willingness to pay because other factors are more influential.

Participants in the $\mathrm{NHI}$ program in Indonesia have indeed steadily increasing based on BPJS Kesehatan data as of April 2019, so it is hoped that Indonesia can realize UHC [13]. It is proven in this study that the majority of patients $(89.5 \%)$ are participants of BPJS Kesehatan insurance. These results are similar to the previous study which showed that the majority of patients (85.06\%) at PKU Muhammadiyah Bantul Hospital used BPJS Kesehatan insurance, which the government paid for medical expenses [11]. Insurance ownership did not affect the patiens' willingness to pay out of their own pocket for outpatient services for the internal medicine clinic at RSU Kota Tangerang Selatan, in contrast to other studies which stated that there is an effect of insurance on the willingness to pay. This happened because previous research had focused more on whether or not the respondent had insurance, not the type of insurance the respondent had. The majority of respondents in the previous studies did not have health insurance, thus affecting the low willingness to pay $[14,15]$. The results of this study further indicate that both BPJS Kesehatan insurance participants and private insurance participants have a high willingness to pay, so the type of insurance owned by the patient does not affect the willingness to pay. This result was obtained because the patient's perception of health was quite high, so that most patients have the awareness to prioritize their recovery and health even though they have to pay out of pocket.

\section{Conclusion}

Based on the results and discussion, it can be concluded that the factors of income, treatment experience, and ability to pay affect the patients' willingness to pay out of pocket for outpatient services in the internal medicine clinic at RSU Kota Tangerang Selatan. Improving service quality, including providing good information, can be done to increase patient loyalty so that it can increase the patients' willingness to pay. Further research is needed in all outpatient clinics so that the data are more representative of all outpatients. 


\section{References}

1. World Health Organization. Technical Report Series No. 122 [Internet]. 1957. Available from:

https://apps.who.int/iris/bitstream/handle/10665/40375/WHO_TRS_122.pdf;jsessionid=F973 2DEC4B2D51E76390056329C3EA38? sequence $=1$

2. Sabri F, Amelia R. Analisis Willingness To Pay (Wtp) dan Kebutuhan Air di Kecamatan Merawang. INFO-TEKNIK. 2016;17(2):235-252.

3. Nugraheni WP, Pusat Humaniora dan Manajemen Kesehatan, Badan Penelitian dan Pengembangan Kesehatan Kemenkes RI, Hartono RK, Sekolah Tinggi Ilmu Kesehatan Indonesia Maju (STIKIM). Analisis Pola Layanan Kesehatan Rawat Jalan pada Tahun Pertama Implementasi Program Jaminan Kesehatan Nasional (JKN). Media Penelit dan Pengemb Kesehat. 2017;27(1):9-16.

4. Khalid S. Sistem Rujukan Terintegrasi (SISRUTE). Sistem Rujukan Terintegrasi. 2019. Available from: http://www.depkes.go.id/resources/download/info-terkini/rakerkesnas2019/SESI II/Kelompok 2/1-Sistem-Rujukan-Terintegrasi-Sisrute.pdf

5. RSU Kota Tangerang Selatan. Laporan Kinerja Instantsi Pemerintah 2018. Tangerang Selatan; 2018. Available from: https://rsu.tangerangselatankota.go.id/wpcontent/uploads/2019/05/LKIP2018.pdf

6. Notoatmodjo S. Metodologi Penelitian Kesehatan. 2nd ed. Jakarta Rineka Cipta; 2012.

7. Noormalasari W, Sandra C. Kemampuan Membayar luran Jaminan Kesehatan Nasional Bagi Nelayan di Kabupaten Jember (Ability To Pay The Premium Of National Health Insurance For Fisherman in Jember). Jurnal Pustaka Kesehat. 2015;3(1):147-54.

8. Zheng $Y$, Huang $Z$, Jiang $T$. Will the economic recession inhibit the out-of- pocket payment willingness for health care? Int J Environ Res Public Health. 2020;17(3):713.

9. Audureau E, Davis B, Besson MH, Saba J, Ladner J. Willingness to pay for medical treatments in chronic diseases: A multicountry survey of patients and physicians. J Comp Eff Res. 2019;8(5):357-69.

10. Ossai EN, Fatiregun AA. Clients' willingness to pay for immunization services in the urban and rural primary health centers of Enugu state, Nigeria. $J$ Public Health Africa. 2016;6(1):20-24.

11. Mudayana AA, Rusmitasari $H$. Analisis Kemampuan dan Kemauan Membayar Pasien Rawat Inap Di RS PKU Muhammadiyah Bantul. KESMAS. 2015;9(1):45-52.

12. Londo JP, Tucunan AAT, Maramis FRR. Hubungan antara Karakteristik Peserta BPJS Kesehatan dengan Pemanfaatan Puskesmas di Wilayah Kerja Puskesmas Tahuna Barat. KESMAS. 2017;6(3):1-7.

13. Nurvita S, Sekolah Pasca Sarjana Kesehatan Masyarakat Universitas Diponegori. Gambaran Kepesertaan JKN Tahun 2019. J Manaj Kesehat Indones. 2019;7(3):217-22.

14. Azimatun NA, Syed Mohamed AJ. Willingness to Pay for Outpatient Services User Fees: Malaysian Community Perspective. J Sains Kesihat Malaysia. 2018;16(1):145-53.

15. Innocent J, Handrof E, Matro JM, Wong Y-N, Chertock Y, Daly MB, et al. Patient interest and willingness-to-pay (WTP) out-of-pocket (OOP) for comprehensive tumor genetic profiling (CGP). J Clin Oncol. 2015;33(15):1545-1545. 